\title{
Lederartikkel til temaseksjon: Pedagogilkk og kritikk
}

\section{Einar Sundsdal}

Institutt for pedagogikk og livslang laring, NTNU, Norge

En av målsettingene med å etablere tidsskriftet Nordisk tidsskrift for pedagogikk og kritikk var å utvikle et sted for kritiske analyser av pedagogikken og det som foregår innenfor det pedagogiske interesseområdet. Det er det pedagogiske - bredt forstått både historisk og aktuelt - som er vår interesse. Vi ønsker å skape rom for nytenkende og skarpe analyser som åpner nye perspektiver på pedagogiske problemstillinger og institusjoner. Det er et vanskelig prosjekt å lykkes med, og det må anses som en stadig pågående oppgave.

Det er blitt hevdet at det finnes konjunkturer for alt, og kanskje har vi de siste tjue-tretti årene sett en lavkonjunktur for det kritiske elementet i den felles samtalen om pedagogikk. Noen mener sågar at den kritiske tenkningen i samfunnsvitenskapen som sådan har vært satt kraftig tilbake over lang tid. Samtidig er ikke situasjonen for kritisk tenkning helsvart. Var man frimodig kunne man kanskje driste seg til å mene at vi nå er i en slags overgangsfase, både ved universitetene og utenfor, der kritikk og kritisk tenkning gjør seg mer gjeldende. Dette er en tendens vi verdsetter og gjerne vil oppmuntre og bidra til. Det kritiske perspektivet peker på den nødvendige analyse av og diskusjon om pedagogisk teori og praksis. Dette er bakgrunnen for at vi nå har invitert tre fremragende pedagoger til å kaste lys over temaet pedagogikk og kritikk.

Kritikk er en sentral del av den nordiske akademiske diskursen og avgjørende for det intellektuelle livet. I en forelesning om akademisk frihet hevder John Dewey (1902) at kritisk tenkning ofte møter sterk motbør fordi den synes fiendtlig innstilt "overfor vaner og levemåter som folk er vant til [...] og som er verdifulle for folks liv». Dette er særlig aktuelt når det gjelder pedagogiske problemstillinger, eller det Dewey allment kaller «the problems of life». Den som kritisk undersøker problemstillinger som angår folks hverdagsliv og verdier vil ofte bli møtt med dypt festede fordommer og sterke følelsesmessige reaksjoner. Det kreves derfor ifølge Dewey mot å tenke kritisk. Selv om det kan være nødvendig å være modig for å tenke kritisk offentlig - enten det handler om oppdragelse, vurderings- og arbeidsformer i skolen eller barns skjermbruk - mener

^Korrespondanse: Einar Sundsdal, e-post: einar.sundsdal@ntnu.no

(C) 2021 Einar Sundsdal. This is an Open Access article distributed under the terms of the Creative Commons Attribution 4.0 International License (https://creativecommons.org/licenses/by-nc/4.0/), allowing third parties to copy and redistribute the material in any medium or format and to remix, transform, and build upon the material for any purpose, even commercially, provided the original work is properly cited and states its license. 


\section{E. Sundsdal}

Dewey at det individuelle trykket kan avhjelpes av et fagfellesskap som deler en felles forståelse for kritikkens betydning for åpenhet, utvikling og sosiale fremskritt.

Nordisk tidsskrift for pedagogikk og kritikk ønsker å bidra til en offentlighet der pedagogikkens ulike normative, samfunnsmessige, historiske, kulturelle og politiske dimensjoner kan settes under debatt. Vi vil også vise at pedagogikk og kritikk kan gjøres på mange måter. Kritisk tenkning kan ta mange former og gis ulike uttrykk. Vi vil rette en stor takk til Tone Kvernbekk (Norge), Fritjof Sahlström (Finland) og Karsten Tuft (Danmark) for deres utmerkende bidrag til utviklingen av pedagogikk og kritikk i Norden. 